\title{
THE MYTHOLOGY OF THE ARA PACIS AUGUSTAE: ICONOGRAPHY AND SYMBOLISM OF THE WESTERN SIDE
}

\begin{abstract}
Summary: The guiding idea of my article is to see the mythical and political ideology conveyed by the western side of the Ara Pacis Augustae in a (hopefully) new light. The Augustan ideology of power is in the modest opinion of the author intimately intertwined with the myths and legends concerning the Primordia Romae. Augustus strove very hard to be seen by his contemporaries as the Novus Romulus and as the providential leader (fatalis dux, an expression loved by Augustan poetry) under the protection of the traditional Roman gods and especially of Apollo, the Greek god who has been early on adopted (and adapted) by Roman mythology and religion.
\end{abstract}

Key words: Apollo, Ara, Augustus, Pax Augusta, Roma Aeterna, Saeculum Augustum, Victoria

The aim of my communication is to describe and interpret the human figures that appear on the external western upper frieze (e.g., on the two sides of the staircase) of the Ara Pacis Augustae, especially from a mythological and ideological (i.e., defined in the terms of Augustan political ideology) point of view. I have deliberately chosen to omit from my presentation the procession or gathering of human figures on both the Northern and on the Southern upper frieze of the outer wall of the Ara Pacis, since their relationship with the iconography of the Western and of the Eastern outer-upper friezes of this famous monument is indirect, although essential, at least in my humble opinion. Nevertheless, the inner altar with its rich (although badly preserved) iconography is both structurally and ideologically related to all the external walls and their reliefs. I have therefore included this in my presentation. I also consider that, from a mythological and also from a political point of view, the upper friezes of the Eastern precinct wall of the Ara Pacis are complementary to the Western precinct wall's reliefs of the same monument.

The Ara Pacis Augustae was erected (according to the Roman ritual of constitutio) on the 4th of July $13 \mathrm{BC}$, and it was consecrated (according to the Roman rite of dedicatio) on the 30th of January $9 \mathrm{BC}$ Augustus himself had written in his Res Gestae (12) that on the occasion of his safe return from Gaul and Spain, the Senate of 
Rome had decided to build in his honor an Ara of the Augustan Peace, during the consulates of Tiberius Nero and Publius Quinctilius. The 30th of January was the birthday of Livia, Augustus' wife; one cannot affirm, however, in all certainty that the dedication of the Ara Pacis Augustae was deliberately done on Livia Augusta's birthday. According to the Res Gestae 11-13 (mainly 12. 2), a yearly sacrifice should have commemorated this event (the erection of the Ara Pacis in honor of Augustus'return from the provinces of Gaul and Spain). The authorities in charge with the cult sacrifices within the Ara Pacis Augustae were the Roman pagan priests, the Senate of Rome, and the Vestal Virgins. The annual sacrifice was probably meant to commemorate both this event and the peace brought by Augustus' new regime. ${ }^{1}$

This Ara Pacis Augustae was not the only monument of this kind built during the reign of Augustus: to the south of Rome, before the Porta Capena and the temple of Honos et Virtus (the deities of Honor and Courage), there had been constructed another altar, the Ara Fortunae Reducis (the Altar of the goddess Fortuna Redux, the Good Fate that presided over Augustus' happy return from Syria to Rome in the year 19 BC). This Ara Fortunae Reducis was constituta (erected) on the 12th of October $19 \mathrm{BC}$ and it was dedicata (consecrated) on the 15th of December of the same year. In the same area of the Porta Capena, at least according to Livy (1. 26. 2-5), Horatius, the victor over the three Curiatii, had stabbed his sister to death because she dared to weep for her dead betrothed, one of the vanquished Curiatii brothers. One should also remember that two of the Horatii had fallen in this combat between champions (Liv. 1. 25. 14). This mythical fight has united the Latin cities of Alba Longa and Rome, under the leadership of Rome. Both Augustus and the Roman Senate were well aware of the connection between the different historical regions of Rome (such

${ }^{1}$ La RocCA, E.: Ara Pacis Augustae. In occasione del restauro della fronte orientale. Roma 1983, 10-11; in fact, the emphasis Augustus had put in his Res Gestae 34. 1-3 on his role as the Pacator Urbis and on the honours bestowed upon him by the grateful Roman Senate (the clupeus i.e., the shield put into the Curia Iulia for his qualities of virtus, pietas, iustitia, and clementia) is proof enough (at least in my humble opinion) for the image he intended to leave to posterity. According to Suet.' Aug. (28. 2), Augustus himself in one of his edicts proclaimed that he Quam voluntatem, cum prae se identidem ferret, quodam etiam edicto his verbis testatus est: 'Ita mihi salvam ac sospitem rem p. sistere in sua sede liceat atque eius rei fructum percipere, quem peto, ut optimi status auctor dicar et moriens ut feram mecum spem, mansura in vestigio suo fundamenta rei p. quae iecero'. "His good intentions he not only expressed from time to time, but put them on record as well in an edict in the following words: May it be my privilege to establish the State in a firm and secure position, and reap from that act the fruit that I desire: but only if I may be called the author of the best possible government, and bear with me the hope when I die that the foundations which I have laid for the State will remain unshaken"; and Suetonius concluded this passage of the Vita Divi Augusti: 'Fecitque ipse se compotem voti nisus omni modo, ne quem novi status paeniteret "And he realized his hope by making every effort to prevent any dissatisfaction with the new regime". For the Latin original text and the English translation, see Suetonius, Lives of the Caesars. Vol. I. Ed. T. E. PAGE - W. H. D. RousE, with an English translation by J. C. RoLf. London New York [LCL] 1914, 164-165. The study presented here continues essentially the line of research begun by the author with his previous published studies in English that are mentioned at the end of the footnote n. 26 and also in the Italian language by IONESCU, D.-T.: Ara Pacis Augustae: un simbolo dell'età augustea. Considerazioni storico-religiose fra Pax Augusta e Pax Augusti. Civiltà Romana 1 (2014) 75107. 
as the Palatine hill, the Capitolium, the Porta Capena area, and the Campus Martius) and the founding myths of Rome.

According to the myth and legend narrated by Livy (1. 16. 1-2), Romulus himself was mustering his army on the Campus Martius (the field dedicated to the war god Mars) near the Caprae palus (swamp of the goat), when he was taken from there to Heaven by the gods, as Julius Proculus reported to the bewildered Romans (Liv. 1. 16. 3-8). There, in the time of Romulus, was built an altar to Mars (Ara Martis), and this field was destined to be used for the military exercises of the first Roman armies, the dilectus (recruitment) of the future young soldiers, the military and athletic contests of the Roman youth, and finally for the assemblies of the Comitia Centuriata (it was initially the military assembly of the Roman people in arms, grouped into classes and divided into centuriae that elected future magistrates endowed with the power of military commanders). In this field dedicated to Mars and to the Roman Iuventus (and therefore to the future of the Eternal City) it was consecrated by the Roman Senate to be an altar to the Augustan Peace. ${ }^{2}$

The Ara Pacis was integrated into a system of monuments in the northern part of the Campus Martius: the Mausoleum Augusti, the Meridianum/Horologium Solarium Augusti, the Ustrinum Augusti, and the Pantheon. In the Res Gestae Divi Augusti 11-13, one can read over a span of time of two millennia Augustus' very words: he basically wrote that the Roman Senate had ordered that the Ara Fortunae Reducis and the Ara Pacis Augustae be built in his honor and that sacrifices were to be performed there in his honor by the magistrates, the priests, and the Vestal virgins. There is an obvious correlation between the architectural and sculptural monuments that were mentioned in the Res Gestae and the very text of the Res Gestae; one can find here the ingenious device of the political ideology promoted by Augustus. That was in fact the official initiative of the Senate, and thus the continuity between the new regime of personal power and the old republican forms of government were apparently ensured. Although it may appear a bit far fetched and anachronistic, this was in fact true political propaganda. Nevertheless, it was a shrewder move than the mere proclaimation of the virtues of the Princeps himself: it was in fact the old representative institution

${ }^{2}$ PONTI, E.: Ara Pacis Augustae. Origine-Storia-Significato. Roma 1938, 11; LA RoCCA (n. 1) 11; SetTis, S.: Die Ara Pacis. In Kaiser Augustus und die Verlorene Republik. Mainz am Rhein 1988, 401; in fact, these two phases in the building and consecration of the Ara Pacis Augustae are mentioned by Ovid (Fasti 1. 709). The date of 4th of July as the Constitutio of the Ara Pacis is given also by the Fasti Amiternini and by the Fasti Antiates. According to both the Fasti Amiternini and with the Res Gestae 12. 2, the Constitutio Arae had taken place in the year 13 BC, under the consulship of Tiberius Nero and Publius Quinctilius Varus (the future Roman army commander responsible later in the AD 9 for the disaster of three Roman legions and nine auxiliary units in the Teutoburg Forest, see MuRDOCH, A.: Rome's Greatest Defeat Massacre in the Teutoburg Forest. Gloucestershire 2006, 55-56, both Tiberius and Varus appearing as consuls on the southern frieze of the Ara, between Augustus and the Flamines) and the Consecratio/Dedicatio Arae Pacis Augustae had taken place on the 30th of Januray (Livia's birthday), according to the Acta Fratrum Arvalium, to the Fasti Caeretani, to the Fasti Verulani, and also according to the Fasti Praenestini. Moreover, the Fasti Praenestini contain the valuable information that the Dedicatio Arae Pacis has taken place during the consulship of Drusus and Crispinus that was in the year 9 BC (see above SETTIS 400-401). 
of the Res Publica, the Roman Senate that empowered the magistrates, the pagan priests, and the Vestals to sacrifice on this altar in honor of the Pax Augusta. ${ }^{3}$

I should mention that I have begun with the assumption that the Ara found in the area of San Lorenzo in Lucina, underneath the foundations of the Ottoboni-Peretti-Fiano-Almagià palace, was the true, above-mentioned Ara Pacis Augustae. In fact, although the majority of the scholars admit that identification, there are other scholars who doubt or even deny that allegation. ${ }^{4}$ Nevertheless, for the start we shall begin this study with the assumption that the Ara found underneath the foundations of the Palazzo Ottoboni-Peretti-Fiano-Almagià is the true Ara Pacis Augustae.

Before discussing the period of foundation of the Ara Pacis Augustae, one should consider the construction of the Ara Fortunae Reducis, near the temple of Honos and Virtus at Porta Capena. The erection of the Ara Fortunae Reducis was preceded by the ceremony named ire obviam, "going to encounter" the main character of this ritual, in this case Augustus himself. The consul L. Lucretius, some of the praetors, some of the tribuni plebis, and some of the senators went to Campania in order to meet Augustus returning from Syria. This event happened, as we have mentioned above, in the year 19 BC. It was therefore a kind of precedent to building the more important Ara Pacis Augustae some six to ten years later, from 13-9 BC to honor Augustus' return from Gaul and Spain. ${ }^{5}$

The original western and eastern facades of the Ara Pacis Augustae represent, on their upper level, panels with friezes describing mythological subjects; thus the reconstructed upper north-western panel of the Ara Pacis represent the Lupa Capitoli$n a$, the she-wolf of the Capitolium hill, and the twin brothers Romulus and Remus, who are seen here as the suckling whelps of the female wolf, on the Palatine hill. The

${ }^{3}$ ZANKER, P.: Augustus und die Macht der Bilder. München 1987, 126-127.

${ }^{4}$ WeInStock, S.: Pax and the Ara Pacis. JRS 50 (1960) 58 apud SchÜTZ, M.: The Horologium on the Campus Martius reconsidered. JRA 24.1 (2011) 86.

${ }_{5}^{5}$ LA RocCA (n. 1) 9-11; as a matter of fact, the Augustan ideology of power has vacillated between the image of the young and new Caesar Octavian (at the very beginning of Caius Octavian's spectacular political career at the young age of nineteen years old struggling to be seen as the rightful and

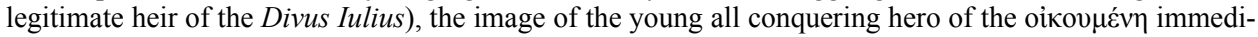
ately after the victorious battle of Actium (2nd of September 31 BC) and the conquest of Egypt (30 BC) Caesar Octavian as the victor terra marique, the pacator orbis, the dominus mundi (in fact this image is going back to the icon of the ideal Hellenistic King, the new Alexander the Great as a kind of kosmokrator), and finally to the image of the mature Imperator Caesar Augustus, the benevolent patron and protector of the res publica restituta. This last and final image Augustus has chosen to leave of himself to posterity is paradoxically more tributary to the ideals of the Optimates leaders such as Cato the Younger, as the great Pompey in his mature age, and as M. Tullius Cicero, men hostile to the res novae, than to the ideas of the populares leaders such as C. Iulius Caesar. To be fair and square, the young Octavian at the very beginning of his political career bore more resemblances with a Catilina type of leader than to the image of the Princeps Senatus the stern guardian of the mos maiorum who, according to his very words in the Res Gestae 34. 3: Post id tem[pus] auctoritate [omnibus praestiti, potes] tatis au[tem] nihilo amplius [habu] i quam cet[eri qui] mihi quoque in ma[gis]tra[t] u conlegae [fuerunt]. "After that time I had outdone all in prestige/influence (auctoritas), nevertheless I had no more legal power (potestas) than the others who were my colleague officials (magistratus)" (here the English translation from Latin is mine). See LANA, I. - De Biasi, L. - Ferrero, A. M. (eds.): Gli Atti Compiuti e i frammenti delle opere di Cesare Augusto Imperatore. Torino 2003, vol. I-II [Classici Latini Collezione Fondata da Augusto Rostagni Diretta da Italo Lana]. 
bearded war god Mars, fully armed and in full armor, is behind the wolf, and behind her are the two human cubs. In front of her is a herdsman (perhaps Faustulus; we should return later on the identity of this character) leaning on his long staff. In the background there is a tree and a bird on a tree's twig. We shall later come back to the full mythological significance of these images. This upper panel was badly damaged during the course of time and it was heavily reconstructed by modern restorers. The south-western (i.e., to the southern corner of the western façade) upper panel of the western façade of the Ara Pacis, one of the best preserved friezes of this monument, represents the scene of a sacrifice: a mature, bearded man with veiled head (velato capite), is probably in the act of pouring a libation from a (now lost) vessel onto an altar (the palm of his outstretched right hand is missing); two young boys (perhaps young teenagers consecrated to the gods, camilli pueri) are bringing an animal (a sow) for sacrifice. The Camillus in front of the bearded and head veiled man is bearing in his upheld and elbow bent left hand a ritual saucer ( $\operatorname{lan} x$ ) with fruits on it; in his right hand, that hangs along his body, he holds a kind of jar used for pouring drinks or libations. The other Camillus (or rather a victimarius) ${ }^{6}$ that comes close behind is driving the sow to the altar. Behind the bearded man there is a partially recognizable young male figure with long hair that holds straight up with his right hand (the arm being also elbow bent) a kind of long spear or long staff (maybe a scepter?). In the uppermost corner of the panel, right behind and up from the heads of the camilli, there is the representation of a rectangular temple with a triangular upper front.

${ }^{6}$ REHAK, P.: Imperium and Cosmos. Augustus and the Northern Campus Martius. Ed. by J. G. YounGER. Madison WI. 2006, 113-115 and respectively 116-117; for the identification of the herdsman in the scene representing Mars, the twins, and the lupa, most scholars have opted for Faustulus. However, D. CASTRIOTA (The Ara Pacis Augustae and the Imagery of Abundance in Later Greek and Early Roman Imperial Art. Princeton 1995, 154-155) because of the garment worn by the supposed shepherd and also because of the sheer length and type of his staff, believes that the so called Faustulus shepherd is in fact the maternal grandfather of the twins, King Numitor of Alba Longa (see CASTRIOTA 156-157 and 160161). Nevertheless, during that mythical time when Romulus and Remus were nourished by the she-wolf under the guardianship and protection of their divine father (the war god Mars), King Numitor of the city of Alba Longa who was the father of the Vestal Rhea Silvia (the human mother of Romulus and Remus) was imprisoned by the orders of his own brother, the usurper Amulius. It is hard to conceive here that the artist who actually carved the scene or the designer of this scene (or even more so their supervisor) to have so blatantly violated the logic of the Roman founding myth as to represent Numitor in a scene where Faustulus was a far more appropriate character (Livy 1. 3. 10-11;1.4. 1-9). The reconstructed tree and the bird sitting on a branch of this tree could either be a recall of Jupiter's protection upon the future founders of Rome (Jove's eagle being the bird) or rather a reference to Mars the divine father of the twins, the bird being actually a woodpecker, an animal consecrated to Mars, like the wolf herself; the tree could well be the Ficus Ruminalis of the Lupercal cavern of the Palatine hill (RossinI, O.: Ara Pacis. Roma-MilanoVerona 2006, 34-35). However, this reconstruction of the western façade (the panel with Mars) is contested by A. DARDENAY (Les mythes fondateurs de Rome. Image et politique dans l'Occident romain. Paris 2010, 97-98 and 103-106) that sees in it the love scene of the encounter between the war god Mars and the Vestal virgin Rhea Silvia (Ilia, the mother of Romulus and Remus). Nevertheless, in that case what would have been the role of Faustulus as by stander? See DARDENAY 97-98: she essentially wrote that this character, leaning on what resembles a long staff, is not in fact Faustulus, but the god Somnus. DARDENAY 103-106 based her demonstration on different examples chosen from the Roman art of the period (1st century $\mathrm{BC}-1$ st century $\mathrm{AD}$ ); if her demonstration is correct, then the entire reconstructed scene with the she wolf (the Lupa) and the Twins (Romulus and Remus) should be revised (because it would have been an anticipation of what was to come, a fact not so common in the ancient Greek and Roman art). 
The main entrance to the interior of the Ara Pacis Augustae was and still is on the centre of the western side of this most famous monument; another symmetrical open gate is also located in the middle of the original eastern side of the Ara Pacis. In this study, as it is generally agreed, we use the original geographical orientation of the facades of the Ara Pacis, as it was originally found in the area of the church and Piazza San Lorenzo in Lucina, buried underneath the foundations of the Palazzo Ottoboni-Peretti-Fiano-Almagià (this palace, built during the Italian Renaissance, is known from the family names of its successive owners from the early 16th to the early 20th centuries).

The eastern façade of the Ara Pacis has two most important upper friezes on this external face of the monument. There is also another entrance into the inner altar on this eastern façade, but because of the higher ground near the prolongation of the Via Flaminia (the ancient "Via Lata", and nowadays the "Via del Corso"), this second entrance has no steps, as does its western counterpart. On the south-eastern corner panel of this façade one can see in its full glory the upper outer frieze representing a seated woman, in all probability a goddess; she wears a long garment that goes up to her ankles, but leaves her upper chest naked, barely covering her breast. Her arms and her neck are almost uncovered except for parts of her long dress that goes around her arms. She wears earrings, her feet are bare, and her head, with curly hair, is covered by a long veil that falls over her neck, shoulders, and back. With her right hand she holds a young child that almost embraces her right breast. In her lap she holds another baby that grabs her left arm. Behind her and in front of her are two seated young women, with naked breast, both having a mantle floating over their head; one of them is sitting on a swan, the other on a kind of dragon. Under these figures are a cow and a sheep, vegetation, and nearby in the background is an overthrown jar in the grass, under the swan. One can see waves under the dragon, probably symbolizing the powers of the sea. The entire picture seems to represent the ideas of abundance, richness, and fertility. ${ }^{7}$ On the north-eastern corner of the eastern façade, one encounters a heavily reconstructed upper frieze panel on the exterior. It represents a seated female deity, wearing a helmet, a sheathed sword at her belt, and a kind of tunic; she is seating on a pile of weapons. Behind her is a young male figure; only his head was relatively well preserved. ${ }^{8}$

${ }^{7}$ SETTIS (n. 2) 413 and 423

${ }^{8}$ There is a great problem in exactly identifying the characters on the western and respectively on the eastern facades of this monument. The mature bearded man, capite velato, who was probably holding a long spear (a hasta that is now almost entirely lost, one can see only its trace on the marble) in his left hand (his right hand, now missing from his wrist, was probably opened in the act of offering or was holding a libation jar), was identified mostly as Aeneas. This was from the time of J. SIEVEKING (Zur Ara Pacis Augustae. JÖAI 10 [1907] 175) and it was generally accepted as an identification by the scholars. Nevertheless, P. REHAK (Aeneas or Numa? Rethinking the meaning of the Ara Pacis Augustae. ABull 83.2 [2001] 190), because the mature man that is the main character of the sacrifice scene appears much more advanced in years than Aeneas at the time of his arrival on the coast of Latium, identifies him with King Numa Pompilius (contra LA RocCA [n. 1] 40-43; RossinI [n. 6] 30-33). The attendant behind this man (of whom we have only a head and a trace of a kind of long staff, either sceptre or shepherd's staff like that of his grandfather's Anchises) was identified either as Aeneas' son Iullus Ascanius or as Aeneas' faithful travel companion Achates (LA ROCCA [n. 1] 40). Nevertheless, his attributed face seems more to 
The idea of symmetry, one could even say absolute symmetry, pervades also the lower external friezes. The entire botanical decoration that fills the lower outer friezes are in fact secondary stems, branches, and twigs of different plants and flowers that spring out from the one central acanthus stem. This central acanthus stem is located on the southern façade under the Flamen, who looks backwards over his own left shoulder, but on the northern façade it is located under the man wearing a pyxis (a kind of box), who, turning his head, also looks backwards.

On the northern and the southern facades there are also secondary axes of symmetry. On the lowest fringe of the vegetal friezes on both the northern and southern facades are situated small animals: a snake that tries to get to a bird's nest filled with young birds, with one of them getting out of the nest in the opposite direction to save its life: probably an allegory or symbol of the struggle between life and death; there are also a frog and two lizards. The animals are in symmetrical positions; there is a perfect correspondence between their respective positions on both the northern and southern facades. On the eastern and on the western façades, both interrupted by the empty spaces of the respective gates, each lower frieze panel has its own axis of symmetry, represented by a central acanthus stem that ends in a trident like shape of a flower. Swans with spread wings appear on all the outer lower friezes. On the upper fringes of the lower friezes, they hover over the flowers that end the acanthus' axes of symmetry. One can number six swans on each of the longer, lower, northern and southern friezes and four swans (distributed in two pairs, a pair on each of the panels) on each of the eastern and western facades. Therefore the total number would be twenty swans (twelve on the northern and southern facades, eight on the eastern and western facades). ${ }^{9}$

The line of separation i.e., the strip of stone that separates the external lower from the upper friezes is a net of intertwined swastikas. Their orientation appears to be in a clockwise direction on the southern façade and in a counter clockwise direction on the northern façade. On the western side, under the frieze with Mars and the twins (Romulus and Remus), the decorative separation swastikas are oriented in a clockwise direction, while on the western panel, with the sacrifice scene, it is oriented in a trigonometric (counter-clockwise) movement. On the eastern side, in symmetrical opposition to the panel with Mars and the twins, the so-called Dea Roma panel has its underlying separation strip of decorative swastikas in the same clockwise movement towards the right as its western counterpart, while on the so-called Tellus panel the

\footnotetext{
be like that of the type represented by the presumed head of the deity Honos, therefore being more pertinent to the north-eastern corner frieze probably representing the Dea Roma (see MORETTI, G.: L'Ara Pacis Augustae. Roma 1948, 157-159; in fact MORETTI 153-155 attributes this head to the figure behind the Aeneas panel, identifying this elusive attendant of Aeneas either with Achates or with Eubuleus, but it is more likely that this head belonged originally to the Dea Roma panel, see LA RoCCA [n. 1] 50-51). R. PARIBENI (Ara Pacis Augustae. Roma 1932, table 13) identifies this head of a young male god/hero (demigod) possibly with Bonus Eventus. The same problem of multiple possible identities is with the goddesses that appear on the eastern façade and their attendants and we shall dwell upon this problem later on in this article.

${ }^{9}$ See Simon, E.: Ara Pacis Augustae. Greenwich, Conn. 1968, 14 on the idea of symmetry that pervades all aspects of the friezes of the Ara.
} 
underlying decoration is oriented counter-clockwise, exactly the same as on the corresponding western panel with the sacrificial scene (the so-called Aeneas/Numa panel).

Thus the symmetrical composition of the whole monument is reinforced by the opposite orientation of the intertwined swastika decorative motifs on the southern and on the northern sides of the Ara, suggesting the complementarities of the two procession scenes: they could well be the two halves of the same procession, assembled in a symbolic gathering face-to-face, on the western entrance to the monument. It seems that the direction of the processions on the northern and on the southern façade is from the east to the west. On the western and on the eastern facades, however, there is a different kind of complementarity: the western panel with Mars and the Twins (Romulus and Remus) has the intertwined swastika decoration underneath oriented exactly the same as does the eastern side, the Dea Roma panel (i.e., clock-wise) on. Under the western panel with Aeneas/Numa and his two sacrificial attendants (the young Camillus and Victimarius) as well as under the so-called eastern Tellus/Pax panel the decoration of intertwined swastikas is oriented counter-clockwise. Therefore the opposite corresponding panels have the same orientation of decoration underneath, while the panels located on the same side (eastern and respectively western) they seem to have opposite-directed-decorations underneath. One can further speculate on the possible symbolic meaning of these subtle changes of direction of the dividing swastikas, which nevertheless stress the complementarities between the four facades.

The complementarily association or combination that appears on the floral friezes, between the ivy and grapevine on one hand, and the laurel on the other, was also interpreted, on the basis of Hellenistic artistic influence (mainly from the sculpture of Pergamon/Pergamum), as the concordant and complementary pair of gods, Dionysus and Apollo. This harmonious association of the two gods was a prerequisite to Concordia/Homonoia and Pax/Eirene. ${ }^{10}$ In Pergamene art (sculptural reliefs or frieze slabs) there appear numerous mythological scenes that represent or allude to, both directly in a figurative way and indirectly via different plants (such as the acanthus, the grapevine, the ivy, laurel, wheat, pine, quince, wheat, olive, pomegranate, etc.), different goddesses and gods: Rhea-Kybele, Aphrodite, Demeter, Hermes, Dionysus, Apollo, and Artemis, but also Persephone, Leto, Ploutos, Triptolemos, Heracles, Eumolpos, and Eros. ${ }^{11}$ In conclusion, the botanic symbols of the Ara were already prefigured by the sculpture of Pergamon.

However, there is more at work here than merely the transmission of floral motifs from Greek and Hellenistic art to Roman art; the laurel and the ivy, as joint symbols of Apollo and Dionysus, allude both to nature or universe (physis, kosmos) and to the mystical unity between these two apparently contradictory gods, as Plutarch in his Moralia 388 F wrote that the fire (pyr) aspect of God (Theos) is called Phoebus

${ }^{10}$ CASTRIOTA (n. 6) 20-21; for the different species of plants represented on the lower outer reliefs of this Ara, one must see CANEVA, G.: Il codice botanico di Augusto. Ara Pacis: parlare al popolo attraverso le immagini della natura [The Augustus Botanical Code. Ara Pacis: Speaking to the People through the Images of Nature]. Roma 2010, 46-47, 54, and passim. But see now the paper of M. SCAPINI in this volume pp. 185-209.

${ }^{11}$ CASTRiota (n. 6) 14-19. 
Apollo, while in his aspects of water (hydor), winds (pneumata), earth ( $(g \bar{e})$, stars (astra), plants and animals (phyta, zoa) is called Dionysus, Zagreus, Nyktelios, and Isodaites. Therefore the God of Solar Light was called Phoebus Apollo (Phoibos Apollon, the first element being clearly related with Phos i.e., Light) and the God of Nature (Physis) in his dynamic aspects of transformation or metamorphosis was called Dionysus; for the initiated priests of the mysteries of Delphi, the two gods were but two different and complementary aspects of the same deity (and Plutarch himself was initiated as a priest at the oracle of Delphi). ${ }^{12}$

\section{THE INNER ALTAR: ICONOGRAPHY AND ROMAN RELIGION}

The person that enters into the Ara from the original western gate must ascend a marble stairway of nine or ten steps until he or she arrives on the inner platform; in order to climb to the inner altar for performing the sacrifice, the pagan Roman priest had to climb another eight or nine steps of marble. In all, the stairway has eighteen steps. The inner altar has as external decorations griffins on its own upper precinct walls and it probably had three levels of outer decorations and two inner friezes (these are still clearly recognizable, especially the inner one on the original northern wall of the inner altar). On the inner side of the facade walls, therefore, in an opposite position to the external decorations of the inner altar, there is a different decorative pattern of boukrania/boukrana (ox skulls), ritual saucers (paterae), and garlands. This is a clear hint to animal sacrifices. Moreover, there is a series of narrow openings on the platform level of the external facades; in fact these are narrow channels that go through the external facades of the Ara, meant probably as a draining system for rain water (it is difficult to think of these channels as being intended for the flowing of the blood of sacrificial victims, because, if there were animal sacrifices performed on this Ara, the blood of the animal victims would have flown on the steps of the inner altar and then, from the platform it would have dripped on the steps that lead from the western entrance to the ground level of the Tiber shore). ${ }^{13}$

The preserved decoration on the outer and upper northern part of the inner altar represents a sacrificial procession; there are represented here a young attendant (a boy consecrated to the gods i.e., a Camillus) that leads the sacrificial procession, followed by a priestly figure dressed in a kind of toga (a vir togatus), and two lictores; the animals to be sacrificed are a sheep that marches in front and two cows, as victims of a preliminary sacrifice to Janus (a god closely associated with Pax) and to Pax

${ }^{12}$ CASTRIOTA (n. 6) 108-109, n. 82 on the Numen mixtum Apollo-Dionysus; this divine force (numen, Deus) is seen as the Light of the Sun (and symbolically as the light of understanding or of the intellect) in the form of Apollo and the same divine force converted into the vital power of life (the force/ $\delta$ v́v$\mu \iota \varsigma$ of life in action) is viewed as Dionysus.

${ }^{13}$ This mental reconstruction of the functionality of the Ara is of course valid only if this monument is truly the Ara Pacis Augustae mentioned by the Res Gestae 12. 2; contra WeINSTOCK (n. 4) 4458; there are four draining channels on each northern and respectively southern external side of the Ara, and two draining channels (one on the basis of each half) on the eastern and respectively western outer side of the Ara. 
herself. A few young men dressed in short kilts called limus are guarding, driving and attending the animals destined for sacrifice. ${ }^{14}$ On the inner face of the same part of the inner altar there is cut in stone a procession of female figures, possible of Vestal virgins; on the opposite southern part of the inner altar, there are also scarce preserved fragments of inner and outer reliefs. From these friezes very few parts of human bodies were preserved and we could assume, based on the friezes on the northern upper part of the inner altar, that here were also religious rituals, hewn in stone. ${ }^{15}$ There were also, however, two other lower levels of friezes on the external northern, eastern, and southern sides of the inner altar; nevertheless the decorations are not at all preserved and there are only unrecognizable traces of the original patterns that were once cut into stone. On the western side, the inner altar is open, because it was there that sacrifices, offerings, and possibly also other religious acts (such as libations, prayers, etc.) were introduced. The inner Ara was thus, from the sacrificier's point of view, the most important component of what, in this particular case, we name the Ara. In fact the inner altar was the true sacrificial altar and therefore the religious nucleus of the entire structure.

In the case of the outer precinct walls with friezes, it appears that the marble friezes were superimposed on square blocks of volcanic tufa and of travertine and above the basis of the whole structure lies the layer upon which all these are built a layer that is pierced by the above-mentioned outlets for draining the rain water (four each of the northern and southern sides, two on the eastern and on the western side). ${ }^{16}$ The corners of the precinct walls are adorned with four pilasters with Corinthian decoration and the inner decoration of the upper level of the precinct is made up of boukrania, of a kind of ritual saucers (paterae), and of garlands made out of plants (fruits and leaves). The Corinthian type pilasters appear also as boundary markers of the frieze panels on the eastern and western facades. On the contrary, the inner altar, being the nucleus of the whole open (roofless) structure, has no pilasters at all. Instead, its four upper corners are ornate, with lion-headed griffins that have a double tail (on the

${ }^{14}$ Simon (n. 9) 15; Holliday, P.: Time, History, and Ritual on the Ara Pacis Augustae. ABull. 72.4 (1990) 552-553 describes more accurately this sacrificial procession as that of the young Camillus holding an acerra (a casket for incense), the togatus priest, the lictor of the priest, the other sacrifice attendant called the calator; the sacrificial animals are the ram and the steer as preliminary victims destined to the gods Janus and Jupiter and a heifer or goat as the sacrificial victim for the goddess Pax herself. Ten victimarii are following with the animals, among them two popae (one with a culter or long knife and one with a kind of hammer/malleus, mace, or axe that is another kind of weapon made for the animal sacrifice); there are other two attendants that carry different things, one a kind of sacrificial knife (culter) on a platter and another the ladle (simpulum) and pail (situla) for the entrails of the slaughtered animals (exta). Another Camillus closes this section of the procession.

${ }^{15}$ HoLlidAY (n. 14) 552-553: six Vestal Virgins represented on the inner face of the northern inner altar advance in a slow motion; they have different sizes (statures) but the same clothing. Each of them wears a suffibulum, a white head covering bound under the chin and a mantle closely wrapped around their bodies. The first one carries a spherical incense jar, the second one a simpulum, and the third and fourth tablets with written ritual prescriptions. The last two Vestals appear to bear no object at all. The six Vestal priestesses are preceded by two togati characters, a young attendant and, in front of him, an assistant carrying the double rods. The entire procession is ended by another male attendant that carries also the same insignia (i.e., the double rods).

${ }^{16}$ SIMON (n. 9) 9. 
inner and outer sides of the inner altar's corners), a typical motif of the arts of the Near East and of the Middle East. ${ }^{17}$ The inner side of the external precinct walls is divided on three decorative levels (the upper one with boukrania and garlands, the separation band of decoration with upright palmettes and lotus buds, and the lower level decorated with vertical "laths" (grooves and ridges). ${ }^{18}$ The sacrificial altar is accessible through a stair of eight steps, starting from the inner platform. The priests who performed the sacrifice would have ascended the first nine steps, starting from the western entrance, and upon stepping on the tenth they would find themselves on the inner platform of the monument. From there they would have more seven steps to climb, until they trod on the eighth of these steps, which is the altar table. The basis of the sacrificial table of this altar was constituted by the four great marble steps of the series of eight steps that leads to the sacrificial table proper. They were originally cut into the tufa foundations that still exist under the Palazzo Peretti-Fiano-Almagià. The fourth one constituted the platform of the altar pedestal or the prothysis, the place were stood those who offered sacrifice. ${ }^{19}$ The last four steps lead to the sacrificial table or small platform of the inner altar.

The general ideas suggested by the external and internal friezes of the Ara Pacis Augustae could have been manifold: one should insist only here on the ideas of the cosmic time cycles and of the renewal of the Golden Age (Aurea Aetas) during Augustus' reign, without the necessity of a cataclysmic or catastrophic change. ${ }^{20}$

${ }^{17}$ SIMON (n. 9) 11.

${ }^{18}$ SIMON (n. 9) 10; thus it is created for the viewer the impression of a (in reality fake) fence, although the "laths" i.e., grooves and ridges are only decorative in their role as a precinct wall; see REHAK (n. 6) 103.

${ }^{19}$ SIMON (n. 9) 10-11, and plates 1-2.

${ }^{20}$ Holliday (n. 14) 542-557; Rome during Augustus' lifetime was already permeated by ideas of the cyclical time. These concepts originated both from the Roman (Etruscan and Italic Indo-European) religious beliefs as well as from Greek-Hellenistic (mainly Stoic Philosophy), Babylonian, and Iranian conceptions of cyclical time. It is not at all impossible that Indian ideas of cyclical time to have been known to the ancient Romans, of course most probable through Iranian (Parthian and Persian), Babylonian, and Hellenistic Near Eastern intermediaries. Anyway, the conception of cyclical time (anacyclosis) was not confined in Antiquity to India and the Middle East or to Greece; in the European Far West the Celtic Druids had also the idea of the cosmic cycles, at least judging from the Celtic myths and epics preserved in later Briton (Welsh/Cymru) and Gaelic (Old Irish and Middle Irish) written versions. The Germanic (Old Norse) mythology (known to us only in a late variant already influenced by Christianity at the beginning of the 2nd millennium of the Christian era) also had a conception of cyclical time, clearly expressed by the Icelandic Edda. However, all these religious ideas underlined the end of the world through Fire (the Ekpyrosis mentioned by Heraclitus of Ephesus and later by the Stoic philosophers) or through a radical and drastic renewal (metacosmesis/diacosmesis) that implies destruction of the previous order or kosmos. The first great Roman and Latin epic poet, Ennius, was conscious in his Annales (frags. 96-100) of the symbolic significance of the eagles seen by Romulus: the twelve eagles seen by Romulus from the Palatine hill as flying ter quattuorque (in three groups of four birds each) were symbols of the one hundred and twelve years or (after the passing of that period) of the twelve saecula (a saeculum was approximately one hundred or one hundred and ten years) given to Rome for existence. Later the Neo-Pythagorean philosophers and the Stoics brought to Rome the ideas of the Magnus Annus or the Great Cosmic Year (a Cosmic Cycle). Gradually, the idea of cosmic year permeated the Roman religious mentality of at least a part of the educated aristocratic elite. After the end of the civil wars, Augustus was seen as the Dux Pacificus, the bringer of peace. His political gestures were made to echo the mythical prototypical gestures of Pater Aeneas and of Romulus. Seen in that perspective, the Ara we are speaking of could be seen 
The southern, uppermost, and external side of the inner altar, as well as the northern one, has two winged lion headed griffins each (oriented towards the west and towards the east) as the four symbolic guardians of the altar. ${ }^{21}$ The decoration that continues from the griffins' tails is formed of S-shaped acanthus volutes; while the northern side of the inner altar has both a considerable part of the external and of the internal decoration preserved (speaking about the upper level, located just under the griffins), the decoration of the southern side of the inner altar is preserved in a very poor shape, very fragmentarily indeed. Therefore the procession that once stood on the upper outer level of the southern side is reduced to only a few broken fragments of human bodies carved in marble. There are also twelve fragments of decorative frieze that represent draped women; these were ascribed to the podium of the inner altar, although they were not included in the present reconstruction of the Ara. It appeared to have been a complex scene, with at least two women dressed as amazons (in tunics

as conflating the historical and the mythical time in the frieze processions of the outer facades and in the frieze processions of the inner altar, see HOLLIDAY (n. 14) 542-543 and passim. The idea of Roma Aeterna appeared probably also during Augustus' time, possibly under the influence of Cicero's thinking on the cycles of Roman history, see HoLLIDAY (n. 14) 543-544 and 556-557 (an eloquent testimony is the Augustan age poetry of Horace, Ovid, Virgil, and Tibullus). The doctrine of the eternal return or of the cyclical time was familiar to the Greek world: see the idea of the recurrence of political constitutions and of political and military events, the cycle of empires and so on and so forth, in the works of Heraclitus of Ephesus, of Plato, Aristotle, Polybius, in the works of the philosophers of the Stoa, of Sallustius (Catilina 2. 1-6), and of Cicero (De Re Publica 1. 29. 45). See BARKER, E.: From Alexander to Constantine. Passages and Documents illustrating the History of Social and Political Ideas, Oxford 1956, 113, n. 1.

${ }^{21}$ For the symbolic meaning of the griffins, see REHAK (n. 6) 102-103; the apotropaic guardian griffins in Greek mythology were located in the Far North and Far East of the Ancient World known to Herodotus (Hist. 3. 116), as the northern guards of the gold fought for by the Arimasps (Arimaspi, a mythical people located possibly somewhere in the Ural, Central Asia/Altai mountains, or Siberia). However, it can be a matter of discussion whether or not the symbol of the four (winged and lion-headed) griffins was also a sign or an allusion to heroism, preciousness, and the return of the Golden Age (Aurea Aetas), as REHAK (n. 6) 103 suggests. Nevertheless, after the Secular Games (Ludi Saeculares) of the year 17 BC the theme of the Aurea Aetas was very much in vogue in Augustan Rome and the building of the Ara Pacis belongs specifically to this period. The griffins or sphinxes appear also on the shoulders of Augustus' breastplate of the statue from Prima Porta, serving there probably as symbols of the guardians of this world; see ZAnKer, P.: The Power of Images in the Age of Augustus. Trans. by A. Shapiro. Ann Arbor 1988, 192. There would be needed a whole other discussion on the cosmic symbolism of the statue of Augustus from Prima Porta, on the themes of dominion over Space and Time that appear there, on the three cosmic levels represented on the statue's breastplate (the upper level of heavenly and astral deities, the middle level of the realm of men, the lower level of the chthonian deities); see ZANKER 189-192. However, it is only enough to be remembered here a series of diplomatic and military victories that created the Augustan idea of the Parta Victoriis Pax, the peace born out of military victories: the battle of Actium (2 September $31 \mathrm{BC}$ ) and the Roman conquest of Egypt (30 BC), the Roman conquest of the North-Western Spanish (Celtiberian) peoples of the Astures et Cantabri (around 25-13 BC), the conquests of the Alpine Celtic and Rhetic peoples by the Roman armies in the years 16-15 BC, the restitution to the Romans of the Roman military standards captured at Carrhae by the Parthians after tough diplomatic negotiations in $20 \mathrm{BC}$ (a theme exploited heavily by Augustus in the Forum Augustum and the temple of Mars Ultor), the starting of the Roman military conquest of Germany in the years 12-9 BC, and finally the continuation in the same period of the Roman military expansion into the Illyricum (Dalmatia and Pannonia). Around the year 13 BC the might of Rome appeared stronger than ever before, eternal, and unstoppable. This "aggressive peace making" so to speak (or peace in the inside and wars of conquest on the open outer edges of the Roman Empire) is the other side of the coin representing the Augustan period when the Ara Pacis was built. 
that leave one of their breasts naked) and bearing weapons. The functionality of this scene as well as its precise structure remains unclear. There are also five other fragments of larger size, pertaining probably to the lost side-friezes of the inner altar. ${ }^{22}$

The form of the inner altar is that of a rectangular platform with a pulvinar (a projecting terminal) at each end. The eight or nine steep steps give access on the western side to the sacrificial platform, while on the eastern side of the inner altar there are only three or four steps within the enclosure that give access to other pulvinar. This is because of the higher ground on the eastern entrance to the Ara, towards the Via Flaminia/Via Lata, compared to the western side, oriented towards the Tiber. Many altars have been examined as parallels to this inner altar, mainly from the Hellenistic Age altars of Greece and Sicily. These include the highly ornamented altars (Prunkaltäre or "luxury altars") such as the "Nymph Altar" at Knidos, the altar of Dionysus at Kos, the altar of Poseidon and Amphitrite at Tinos, the "Altar Court" at Samothrace (formed of an enclosure wall and an inner altar), as well as the most famous of them all, the Pergamon Altar. The chronological range that includes all these monuments is from the last quarter of the 4th century BC (i.e., during the reign of the Macedonian King Philip III Arrhidaeus, Alexander's first successor) for the "Altar Court" at Samothrace, to the mid-2nd century BC for the Pergamon Altar. The majority of the above quoted Hellenistic altars are from the late 3rd century BC. With regard to the altars' evolution, it is interesting that the Altar Court at Samothrace is without any frieze at all while the Pergamon Altar, a century and a half later, is richly ornate. In fact, the relief decoration of the Pergamon Altar is found both inside and outside the enclosure wall and there is also an inner altar. The artistic style of the Pergamon Altar, being so "baroque" ante litteram, "ahead of its time", making it an uncanny prototype for the Augustan Ara. Classical examples like the Altar of the Twelve Gods in Athens (in the Athenian Agora), because of its structural features (a low enclosure wall with only one entrance) could be dismissed as earlier models for the Ara. Only the Augustan parallels remain, such as the Augustan Age altar at Miletus (an inner altar and an enclosure wall with only one entrance, decorated with figural panel reliefs and a garland frieze), the late Republican Roman temple at Bantia in Southern Italy (in Basilicata), and the temple of Janus in the Forum Romanum, attributed as foundation for the second legendary king of Rome, Numa Pompilius. This temple was the Index Pacis Bellique ("the Pointer to War and Peace") and marked the symbolic passage from one status to another (when the temple doors were closed, it was peace; when they were open, there was war); immediately after the conquest

${ }^{22}$ REHAK (n. 6) 101 with all the references; nevertheless, Rehak's idea of the women being the personification of the pacified provinces of the Roman Empire it remains still a work hypothesis and not a full theory. Otherwise how can one explain the fragments of Amazon frieze sculptures with weapons and therefore not fully vanquished (if they would have been disarmed, although dressed in Amazon tunics it would have made sense; although possibly being still armed they represented regions not fully pacified and only partially conquered by the Roman sword). One should also remember that the very location of the Ara Pacis was in itself important and symbolic: located within a Roman mile north of the pomoerium, the sacred boundary that separated in Roman Antiquity the civilian political power of the Roman magistrates (imperium domi) from the military power of the war time commanders (imperium militiae/militare); see REHAK (n. 6) 98. 
of Egypt (30 BC), in $29 \mathrm{BC}$ the temple of Janus was closed, by the order of the Senate, for the first time during Octavian's lifetime. Of the three closures of the Janus temple, two others occurred during Augustus' reign (Res Gestae 13; Cassius Dio Rom. Hist. 51. 20. 4), probably in $25 \mathrm{BC}$ and in $13 \mathrm{BC}$ (the year of the Constitutio of the Ara Pacis Augustae). Then, in $10 \mathrm{BC}$ renewed hostilities occurred in Illyria and Dalmatia, while between 12-9 BC, after the raids of Julius Caesar in the Germanic lands east of the Rhine, the first Roman military campaigns commanded by Augustus' generals unfolded deep in the lands of the Germania Magna (Germania Libera). ${ }^{23}$

In conclusion, the inner altar (which is the Ara proper, the altar stricto sensu) is ornate with four (winged) lion-griffins that function as apotropaic guardians. They continue a Greek artistic tradition, but also a much more ancient Eastern artistic legacy that dates back to the 3rd millennium BC and had entered Etruscan art in the Orientalizing period of ancient Greek art (the 7th-6th centuries BC). The small frieze near the top of the inner altar occupies a height of about $32 \mathrm{~cm}$ and unfolds over about at least five of the eight available surfaces. On the outer east side of the inner altar one encounters only two preserved figures, a shorter and younger togatus character to the far left and a taller one to the far right. On the southern and respectively on the northern outer sides we have two parallel processions, the direction of movement being apparently from the east end to the west end of the altar, or from the left to the right of the observer on the northern side and from the right to the left of the viewer on the southern side. One can distinguish four victimarii or sacrifice attendants that carry implements and accompany animals destined to be sacrificed; they wear a kind of short tunic (limus) that was worn unfastened from fibulae on the shoulders and rolled around the waist belt, thus freeing both arms for holding and bearing different things. On the inner east side of the interior altar we can see fifteen men and three sacrificial animals, two oxen (bulls or cows) and a sheep. Ovid in his Fasti (1. 720) mentions that a white animal was sacrificed at the Ara Pacis each year, specifying neither the kind nor the gender of the animal to be sacrificed. ${ }^{24}$

The frieze of the inner altar continues on the projecting arms of the inner altar's walls: the inner side of the altar's north arm includes, cut into the stone, a procession of figures moving from left to right: there are thus depicted five female characters (whose dress suggests they are Vestal virgins) of different heights (and thus apparently of different ages), flanked by a pair of male figures. The inner side of the south arm of the inner altar has preserved only two men moving from right to left: one of them is a togatus capite velato (dressed in a toga drawn around his head, with the head veiled) and the other is a flamen i.e., a pagan Roman priest wearing his distinctive pointed cap or hat (galerus). Probably the two processions of the interior sides of the original northern and respectively southern arms of the inner altar were originally

${ }^{23}$ REHAK (n. 6) 99-100; here Rehak thinks that the so called Altar of Piety (Bomos tes deisidaimonias) in Athens was in fact the Altar of the Twelve gods (Bomos ton dodeka theon); see LA RocCA (n. 1) 11-14 and 16 about the link between the garlands and the boukrania with the imperial cult in the Augustan age. However, Augustus was still alive during the first years of Ara's existence and he would have become a god (divus) only after his death, at least in the Latin West of the Roman Empire.

${ }^{24}$ REHAK (n. 6) 101-102 (with all the bibliographical references). 
meeting each other on the eastern interior side, possibly at the center of this eastern inner face. Nevertheless, from this part of the inner altar no other fragments have survived, to enable us to draw some firm conclusions. Less than a half of the inner altar's frieze has survived the ravages of time; as a matter of fact, only thirty-two human figures have survived, of which twenty-seven are males and five are females. This makes roughly the same ratio of men-to-women on the outer friezes of the precinct walls and on the inner altar's friezes. ${ }^{25}$

The western side is the entrance gate for both the precinct outer wall of the Ara Pacis Augustae and for the inner altar. I consider that the choice of the entrance on the western side of the Ara Pacis Augustae by the unknown master architect who had planned the construction of this monument was not a random one; the lay-out of the Augustan monuments on the field of Mars in Rome could be the key to the deciphering of the hidden reasons behind the original orientation of the Ara Pacis Augustae and also of the symbolic significance at least of the upper outer friezes of the precinct walls of the Ara Pacis. This is too long a story to be extensively treated here. There is a deep, although quite obvious symbolism of an Altar of the Augustan Peace located in the Campus Martius, the field consecrated to the warlike Italic god Mars from the oldest times of the origins of Rome. Suffice to say that one should see the Ara Pacis not only as a monument whose iconography reflects the political mythology (or the mythologized ideology) of the Augustan regime; it is also a monument that is a product of the mathematical and astronomical science of the Hellenistic-Roman world, as well as of the technical and artistic expertise of its makers. Last, but not least, it is a smaller reflection or a fragment of a larger world vision. ${ }^{26}$

${ }^{25}$ ReHAK (n. 6) 102.

${ }^{26}$ The list of contributions on this topic is very long; however, I shall quote here the following authors: Rodriguez Almeida, E.: Il Campo Marzio Settentrionale. Solarium e Pomoerium. Atti della Pontificia Accademia Romana di Archeologia. Rendiconti 51 (1978-1980) 195-212; BUCHNER, E.: L'orologio solare di Augusto. Atti della Pontificia Accademia di Archeologia. Rendiconti 53 (1980-1982) 331-345; BUCHNER, E.: Die Sonnenuhr des Augustus. Nachdruck aus RM 1976 und 1980 und Nachtrag über die Ausgrabung 1980/1981. Mainz am Rhein 1982; BuCHNER, E.: Die Sonnenuhr des Augustus. Mainz 1982a; BuChNER, E.: Die Sonnenuhr des Augustus. In HABACHI, L. (Hrsg.): Die Unsterblichen Obelisken Ägyptens [Kunstgeschichte der Antiken Welt Bd. 11]. Mainz 1982b, 240-242; BuCHNER, E.: Horologium Augusti: Neue Ausgrabungen in Rom. Gymnasium 90 (1983) 494-508; BUCHNER, E.: Sonnenuhr des Augustus und römischer Fuss. In Bauplanung und Bautheorie der Antike. Mit Beiträge von W. HOEPFNER ET ALII aus dem Kolloquium des Architekturreferates des Deutschen Archäologischen Instituts. Berlin 1984, 215-218; BUChNER, E.: Horologium Solarium Augusti. In HeILMEYER, W. D. - LA RocCA, E. - MARTin, H. G. (Hrsgg.): Kaiser Augustus und die verlorene Republik. Eine Ausstellung im Martin-Gropius-Bau, Berlin 7. Juni-14. August 1988. Mainz 1988, 240-244; BuCHNER, E.: Neues zur Sonnenuhr des Augustus. Nürnberg 1993-1994, 77-84; BUCHNER, E.: Ein Kanal für Obelisken. Neues vom Mausoleum des Augustus im Rom. $A W 273$ (1996) 161-168; see also BUCHNER, K.: Imperium nullum nisi unum. In L'idéologie de l'impérialisme Romain. Colloque de Dijon le 18 et 29 Octobre 1972. Dijon 1972, 134-145. Contra SCHÜTZ, M.: Zur Sonnenuhr des Augustus auf dem Marsfeld. Eine Auseinandersetzung mit E. Buchners Rekonstruktion und seiner Deutung der Ausgrabungsergebnisse, aus der Sicht eines Physikers. Gymnasium 97 (1990) mit 4 Tafeln, 432-457; SCHÜTZ, M.: Der Capricorn als Sternzeichen des Augustus. A\&A 37 (1991) 55-67; SCHÜTZ: The Horologium (n. 4). For the mathematics of the age, see V. Bummelen, G.: The Mathematics of Heaven and Earth. The Early History of Trigonometry. Princeton-Oxford 2009. There are interesting debates for and against E. Buchner's thesis in HESLIN, P. J.: Augustus, Domitian, and the so-called Horologium Augusti. JRS 97 (2007) 1-20 and 


\section{THE POSSIBLE FORM AND FUNCTION OF THE ALTAR}

It has long been a matter of discussion whether or not animal sacrifices were performed on the Ara that we are currently analyzing in this article. The Res Gestae 12 mention expressly a yearly sacrifice/anniversarium sacrificium that was to be performed on the Ara Pacis Augustae. Nevertheless, it is difficult to imagine the slaughtering of an ox or even of a goat, heifer, or sheep on the small inner altar table. In order to sacrifice there a bull, a cow, a pig, or whatever kind of animal, first the sacrificial victim had to be brought upstairs to the sacrificial table; therefore the animal would have had to be driven to one of the entrances, presumably to the western entrance facing the Tiber shore, although the eastern one would have been more accessible from the Via Lata, with fewer steps to climb to the upper platform; in fact there are only three steps to climb when someone has entered through the eastern open gate. The inner altar, however, is walled and closed on its eastern side. Thus the animal would have had to be dragged upstairs and slaughtered on a truly small upper platform. There is also the alternative view that the sacrificial victim was actually brought to the eastern entrance of the Ara and slaughtered there and then, without entering beyond the precinct walls; in this alternative view, the sacrifice would have happened in front of the precinct of the Ara and not inside it. As a conclusion to this theory, the officiating priests would have entered through the western gate into the Ara, offering bloodless sacrifices of fruits, cakes, and/or wine on the Ara's upper platform, while the bloody sacrifice of animals would have taken place outside the Ara's eastern gate. $^{27}$

There has also been a lot of discussion whether or not the outer southern and northern friezes (hewn on the precinct walls) and also the sacrifice row of characters

\footnotetext{
HESLIN, P. J.: The Augustus Code. A response to L. Haselberger. JRA 24.1 (2011) 74-77, which is generally against E. Buchner's thesis, while L. HASELBERGER (A Debate on the Horologium of Augustus: Controversy and Clarifications. JRA 24.1 [2011] 47-73) and R. HANNAH (The Horologium of Augustus as a sundial. JRA 24.1 [2011] 87-95) are for Buchner's thesis. A more balanced opinion is represented by ALFÖLDY, G.: The Horologium of Augustus and its model at Alexandria. JRA 24.1 (2011) 96-98. As for my humble opinion and ideas in this debate, see IONESCU, D.-T.: Alexander's Monarchy and the Principate of Augustus. Meditating on Relevant Aspects of an Ideological Interface. EDR 13 (2011) 7-75, esp. 60-64; and IONESCU, D.-T.: The Ara Pacis Augustae. Symbolic Iconography and Mythology of the Friezes. EDR 15 (2013) 99-174. The present study is a perfected form of these two previous articles of mine.

${ }^{27}$ ToynBeE, J. M. C.: The Ara Pacis Augustae Reconsidered and Historical Art in Roman Italy [Proceedings of the British Academy XXIX]. London 1953, 73-74; contra REHAK (n. 6) 103 who considers that idea broadly implausible, although even he is forced by the "reality of such cramped quarters" to acknowledge the even narrow plausibility of Toynbee's theory; in truth Rehak considers that in the most general sense, the Ara Pacis served as a memorial and symbol of the Pax Augusta. Inside the Ara there is too little space for allowing such ample processions as those rendered in stone on the southern and respectively on the northern outer friezes of the precinct of the Ara. There is also a too small sacrificial table, located between both sides: the closed eastern side and the open western side of the inner altar. Ovid (Fasti 1. 719) mentions a small fire for burning incense, which is possible to have taken place on the upper inner platforms of the interior altar, but a large fire would have irretrievably damaged the marble, a fact that is not proven by reality.
} 
hewn into stone on the wings of the inner altar represented either the procession that went with the occasion of the constitutio on the 4th of July $13 \mathrm{BC}$ (the date of the building or establishment of the Ara Pacis) or whether it represented the solemn consecration (dedicatio or consecratio) of the altar on 30th of January $9 \mathrm{BC}^{28}$ It is highly probable that the beginnings of these works were accompanied by the religious Roman ritual of inauguratio). ${ }^{29}$

${ }^{28}$ TOYNBEE (n. 27) 74 numbers six Vestal virgins and their attendants (apparitores) with rods on the inner side of the left wing of the interior altar walking ahead of the sacrificial victims and then followed the animals intended for sacrifice: a heifer, a steer, and a sheep (or ram); according to the theory of Mrs. I. S. Ryberg, Toynbee continues, the heifer was the animal regularly offered to the goddess Pax (Peace), while the steer was destined to Jupiter (Iupiter or Jove) and the sheep to Janus (Ianus Bifrons, the two headed Janus). These three deities (Jupiter, Janus, and Pax) were closely associated to each other. These three sacrificial animal victims (the heifer, the steer, and the sheep/ram) are depicted on the outer side of the left wing of the inner altar, along with more apparitores and a priest. MORETTI (n. 8) 282 considers that this was not the ceremony of the Constitutio Arae (4th of July $13 \mathrm{BC}$ ), but the Dedicatio Arae (30th of January $9 \mathrm{BC}$ ); in fact he sees the whole of the processions represented on this Ara as the synthesis of all the important moments of the Ara and of all the rites, rituals, and processions that accompanied the most important moments of its history: the Constitutio Arae (4th of July $13 \mathrm{BC}$ ) and the Dedicatio Arae (30th of January 9 BC). R. BILlows (The Religious Procession of the Ara Pacis Augustae: Augustus' Supplicatio in 13 BC. JRA 6 [1993] 80-92) sees the two phases of Constitutio Arae and Dedicatio (Consecratio) Arae as being one (Constitutio or Dedicatio he uses interchangeably), the event on the 4th of July 13 BC, while (probably for the event that took place on the 30th of January 9 BC) he uses the term Inauguratio (Arae). This thesis (in my humble opinion) is untenable, because the inauguratio took place before the construction (constitutio) of a monument and dedicatio happened after its completion. He nevertheless analyses all the successive theories about the precise functionality of the friezes of the Ara Pacis: 1. Depicting the sacrifice accompanying the dedicatio or constitutio of the Ara (SIMON [n. 9] 16-17; Pollini, J.: Studies in Augustan 'Historical' Reliefs. PhD Thesis. Berkeley 1978, 75-112; LA RocCA [n. 1] 38). 2. The inauguration (inauguratio) performed by Augustus of the terrestrial templum that was destined to become the space occupied by the Ara Pacis Augustae has been treated by POLLINI (n. 29); by TORELli, M.: Typology and Structure of Roman Historical Reliefs [Jerome Lectures 14]. Ann Arbor 1982; and by LA RoCCA (n. 1). 3. The idea that the friezes are depicting "a kind of hidden triumph/eine Art verdeckten Triumphes" (Settis [n. 2] 420) is also rejected by Billows on iconographical essence, as he rejects also the previous two theories. 4. The theory of G. W. BOWERSOCK (in K. A. RAAFLAUB - M. TOHER [eds.]: Between Republic and Empire. Intepretations of Augustus and his Principate. With contributions by G. W. BowERSOCK ET ALII. Berkeley - Los Angeles - Oxford 1990, 392-393) was that the procession on the southern and northern friezes represented an honor bestowed upon Augustus by his family, friends, and also by the heathen priestly ordo of ancient Rome when he became Pontifex Maximus in the year $12 \mathrm{BC}$ instead of his former old enemy and fellow triumvir M. Aemilius Lepidus, exiled at Circei (Billows considers that nothing can support this theory). 5. The showing of a supplicatio (public prayer to the gods) in honor of Augustus, followed by an animal sacrifice; see BILLOWS (n. 29) 80-89. It is clear that the real significance of the outer and inner friezes of this Ara would shed light on the true function of the Ara itself. Billows conclusion nevertheless is that this is probably the true theory on the function of what we use to call the Ara Pacis Augustae. Before Billows, HollidAY (n. 14) 542-557 proposed that the friezes of the Ara represent a generalized or rather a generic supplicatio, a thing that, if proved true, would resolve any issue in this respect; see REHAK (n. 6) 133.

${ }^{29}$ See Holliday (14) 547; in fact, turning again to the Res Gestae 12, one can find (applied to the year 13 BC) the expression: ... aram Pacis Augustae...consacrandam censuit, therefore Augustus himself uses the verb consacrari instead of constituere that has a whole different meaning, a thing already realized by G. Wissowa in 1904; see KOEPPEL, G. M.: Die historischen Reliefs der römischen Kaiserzeit. V. 2: Ara Pacis Augustae. Teil 2. BJb 188 (1988) 97, n. 1-4; see also KoEPPEL, G. M.: Die historischen Reliefs der römischen Kaiserzeit. V. 1: Ara Pacis Augustae. Teil 1. BJb 187 (1987) 102, n. 4. 


\section{THE ARA PACIS AND THE MERIDIANUM/HOROLOGIUM SOLARIUM AUGUSTI}

When anyone speaks about the systems of measuring time in Antiquity, it is compulsory to discuss the different calendars used in Antiquity. We have dealt with this issue before in the course of this study, but we must also draw some applied conclusions to the issue at hand (namely the correlation between the Ara Pacis Augustae and the Montecitorio obelisk/gnomon-meridian system). Assuming that the gnomon-obelisk, the solar meridian or the sundial (Meridianum/Horologium Solarium Augusti), and the Ara Pacis Augustae were interrelated monuments in the web of Augustan ideology revolving on the themes of space, time, predestination, and domination, a discussion about the different calendars used by the ancient Romans and the systems of measuring time in Antiquity is necessary. Even the sole existence of a solar meridian in Augustus' time on the northern Campus Martius makes almost compulsory the mentioning of different systems of measuring time that were in use in Rome during Augustus' reign.

In ancient Rome, Romulus' moon calendar with only ten months was first used. A reminder of this calendar is still to be found in the modern names of the September, October, November, and December months (the seventh, eighth, ninth, and tenth respectively). The wise king Numa Pompilius replaced it with a twelve-month calendar; it was based primarily upon the movements of the sun (it was a solar calendar that preserved the names of the last four months of the previous lunar calendar). Julius Caesar bid a Greek mathematician and astronomer, Sosigenes of Alexandria, to update the old Roman calendar of twelve months, and thus we now have the Julian Calendar with 365 days and $1 / 4$ day for the astronomical year, with a supplementary day every four years (this was basically the Egyptian calendar mentioned by the "Canopus decree" in Ptolemaic Egypt and eventually adopted in Rome by the decision of the young Caesar Octavian in the year $30 \mathrm{BC}$ ). Unlike the ancient Greeks and modern Europeans (and Europe shaped modern cultures on every continent), the ancient Romans placed the pivots or cardines of the sun year, the equinoxes and the solstices, not at the beginning of each season of the astronomical year, but at the middle of the conventional season (Plin. NH 18. 222). A reminiscence of this practice can be seen in the modern distinction established between the beginning of the calendar (seasons of the year): spring, summer, autumn, and winter (respectively the first of March, June, September, and December) and the astronomical respective seasons of the year (21st of March/the Spring Equinox and the beginning of the astronomical spring, 21st of June or the Summer Solstice and the start of the astronomical summer, 21st of September as the Fall Equinox and the beginning of the astronomical autumn, and eventually the 21st of December as the winter solstice and the start of astronomical winter). On the Flavian meridian associated with our obelisk-gnomon, the central point be-

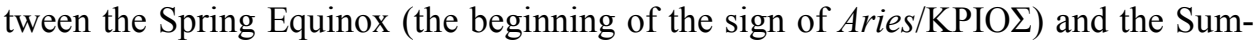
mer Solstice (the first degree in the sign of the Cancer/KАГКРО teenth degree of the sign known as the Taurus/TAYPO $\Sigma$, right where it appears the $\Theta E P O Y \Sigma$ APXH or the Beginning of the Summer, on the same meridian. Therefore, 
although on this Roman age meridian the mathematical and astronomical-astrological concepts are written in Greek, the whole conception of the calendar that revolves around the cardines placed in the middle of the yearly seasons is nevertheless Roman. ${ }^{30}$

The base of the obelisk, which Augustus brought to Rome from Egypt (and placed in the northern part of Campus Martius), according to the report written by J. Stuart in 1750 , as it was found in 1748 during the excavation, ran not with the sides parallel to the meridian and the front perpendicular to it, but turned by fifteen degrees towards the west. Thus the meridian line ran on a South-North direction, while the pedestal of the obelisk had its north-eastern side facing the Ara Pacis, precisely because of this $15^{\circ}$ rotation with respect to the meridian axis. In the 15 th century, this pedestal of the obelisk had been already discovered by the humanist Pomponius Laetus, who wrote that it was surrounded by a seven-step-rectangular stone structure (septem gradus circum) having inscribed on its four angles or corners the Greek names of the winds, such as (in the North-East) BOPEA $\Sigma$. This was done according to Vitruvius's principles, exposed in the De arch. 1. 6. 6-7 and 1. 6. 8. The Hellenistic scholar Timosthenes had already ideated the 12 divisions of the "rose/dial of the winds". Pliny the Elder's remark that "Augustus addidit mirabilem suum" (NH 36. 72) suggests that the system of measuring time (whether horologium solarium or meridianum) was in fact added after the erection of the obelisk in that location and it was possibly not part of the original plan. ${ }^{31}$

The problem of the equinoctial line is whether it truly extended until it reached the Ara Pacis or not; if this was so, then we would probably have a true horologium solarium, defined by two intersecting axes of symmetry, perpendicular on each other. This is only a possibility, not confirmed by any hard fact or archaeological discovery. We are not even sure that the ensemble of the Ara Pacis-Gnomon-Meridian/Horologium was even conceived of from the start as an integrated whole, with a precise aim. The meridian could well have been part of a later addition to the obelisk and not thought of ab initio as the dial for the gnomon. It would have been a necessity only for a $\mathrm{Ho}$ rologium Solarium, the very existence of which is not at all sure. ${ }^{32}$ Moreover, due to the imprecision of celebrating Augustus' precise birthday according to the two Roman calendars already in use under his reign (the old Roman one and the newly reformed Julian calendar, even further improved under Augustus by the application of the early Egyptian reform mentioned in the "Canopus Decree"), the symbolic significance of

${ }^{30}$ SCHÜtZ: The Horologium (n. 4) 81-82, esp. 82, n. 17; contra HASELBERGER (n. 26) 55, n. 9 , based on BuCHNER: Die Sonnenuhr des Augustus (n. 26, 1982a) 63-66 and 79.

${ }^{31}$ SCHÜTZ: The Horologium (n. 4) 83: the Latin verb addere indeed suggests that something not yet existent is created and added to something that is already in existence.

${ }^{32}$ For this theory of the necessity of an Horologium Solarium, see HASELBERGER (n. 26) 68-69; contra SCHÜTZ: The Horologium (n. 4) 83. Nevertheless, even Haselberger points out that, except the obelisk itself, the physical appearance of Augustus' Horologium Solarium was unclear; however it considers the precise alignment of the equinoctial line on the Ara Pacis's axis of symmetry that leads to the western entrance to the monument. This argument is thoroughly and I think soundly combated and refuted by SCHÜTZ: The Horologium (n. 4) 84-85. 
the Ara Pacis as a commemorative monument of Augustus' birthday becomes a little blurred. $^{33}$

However, it remains an undeniable fact that the obelisk was erected sometime between the years 10 and $9 \mathrm{BC}$, just before the Dedicatio or Consecratio Arae Pacis Augustae on the 30th of January 9 BC, Livia's birthday. ${ }^{34}$ It appears much more plausible that the equinoctial lines of the Augustan and Flavian meridians both fell slantwise, in an oblique direction in respect to the axis of symmetry of the western entrance to the Ara Pacis; these equinoctial lines (the Augustan and the Flavian one) would have formed an angle with the line of steps leading to the western entrance, just under the north-western half of the western façade of the Ara. ${ }^{35}$ Accordingly, it appears to me more plausible that Michael Schütz's theory of associating the sculptural, iconographical, and architectural program of the Ara with the feast of the Parilia (21st of April, which was also the Founding Day of Rome in the year 754/753 BC) is correct, although his support of Weinstock's denial of the identity of the Ara was, in my opinion, soundly refuted by Toynbee with logical and iconographical arguments. Most interesting is Schütz's idea that, on the Parilia, the sunrise could have been seen by looking from the eastern portal of the $\mathrm{Ara}^{36}$

There was also a counterattack against Schütz's theory of by Robert Hannah, who defended the thesis of Buchner, basing his argumentation also on Pliny the Elder's Naturalis Historia (36. 72) and the use by the ancients of a "daylight triangle": A represents the noon on the winter solstice while $G$ on the diagram is the gnomon of the sundial. $^{37}$ Pliny the Elder (NH 6. 212) mentions the aequinoctio die medio that is extremely important in the discussion of the existence of a possible Horologium Solarium and its relationship with the Ara. ${ }^{38}$ Moreover, Hannah considers that the affirmations of Pliny the Elder ( $N H$ 36. 72) are not appropriate in describing a solar meridian, but that they are more adequate to describe a solar clock (Horologium Solarium). ${ }^{39}$ We do not know for sure that there has ever been a "daylight triangle" nor a longer equinoctial line as markers of a true Horologium Solarium. The only things

${ }^{33}$ SCHÜTZ: The Horologium (n. 4) 84; moreover, in the Augustan astronomical treatise of Manilius (Astronomica) the term aequinoctium does not appear directly, but it is indirectly marked as the moment when either the day conquers the night or vice versa and the Fall Equinox is for him an intersection between the ecliptic and the celestial equator (Spring or Fall Equinox, see Manil. Astronom. 2. 242; 3. 254 etc. apud SCHÜTZ: The Horologium [n. 4] 84, n. 27); likewise for Ovid in the Fasti (3. 878) the equinox is only the moment when the day and the night have both equal length; therefore there are no deeper symbolic and mythological meanings associated with the equinox, see SCHÜTZ: The Horologium (n. 4 ) 84.

${ }^{34}$ HASELBERGER (n. 26) 69, n. 46

35 SCHÜTZ: The Horologium (n. 4) 85, fig. 2.

${ }^{36}$ SCHÜTZ: The Horologium (n. 4) 85-86, n. 29-30; see Ovid. Fast. 4. 721-862 for the description of the Parilia; for the opposing theories on the true identity of the Ara, see WEINSTOCK (n. 4) 44-58, contra ToynBeE, J. M. C.: The Ara Pacis Augustae. JRS 51 (1961) 153-156. SiMON (n. 9) 9 thinks that the existence of the two portals was not satisfactorily explained. SCHÜTZ: The Horologium (n. 4) 86 admits that in this issue of the gnomon-obelisk, the meridian/sundial, and respectively the Ara "the current state of affairs is admittedly dissatisfying".

${ }^{37}$ HANNAH (n. 26) 88, n. 4, ill. 52.

${ }^{38}$ HANNAH (n. 26) 87, n. 2 .

${ }^{39}$ HANNAH (n. 26) 87-88; moreover, HANNAH (n. 26) 87, n. 4 mentions that there exist at least two mentioned cases of solar meridian and a third case of a vertical instead of a horizontal meridian. 
we do know is that the different instruments used in Antiquity for measuring time were, in form, spherical, hemispherical, and flat/planar; the Horologium Solarium and the Meridianum both enter into the category of flat instruments (i.e., included in a flat surface such as a platea made out of travertine with a marked bronze line in the case of the meridianum and a net of lines in the case of the horologium). According to Buchner's reconstructions the types of horologium solarium are basically of two main forms, one like the spread wings of a bat and respectively circular. ${ }^{40}$ The main argument brought by Hannah against the thesis of Schütz is that he takes into account only the elliptical shadow left by the globe on the top of the obelisk and not the whole length of the shadow left by the entire obelisk. ${ }^{41}$ Bringing in modern-day examples such as the Cenotaph's obelisk from Dunedin (New Zealand), Hannah tries to show empirically that the length of the shadow of Augustus' obelisk (and not only the length of the shadow from its bronze globe located on the top of the gnomon-obelisk) plus the actual penumbra of the obelisk would have pointed towards the centre of the Ara at Augustus' birthday (he means here the total length of the shadow including the penumbra and the shadow left by the tip of the obelisk, i.e., the bronze globe). ${ }^{42}$ The sole problem is that, although the height of the cenotaph's obelisk of Dunedin would be "reasonably close" to the total height of Augustus' gnomon-obelisk, part of the computations made by Hannah are totally approximate and not precise (as are those of Schütz) and his observations are only empirical and based on a single example. ${ }^{43}$ Moreover, because Schütz calculates starting from the elliptical shadow left by the bronze globe located on the top of the obelisk that would mean he took in fact into account the whole length of the shadow left by the entire obelisk, and therefore Hannah's counterargument becomes untenable. ${ }^{44}$ However, as it was previously stated, the exact height of the Augustan gnomon-obelisk is not precisely known, because of the problems involving the number of levels of its pedestal, as it was already shown by the Bandini-Stuart-De Marchis archaeological report of $1750 .^{45}$ In conclusion, all our reconstructions (including the most scientifically grounded, i.e., the theory of M. Schütz) stand on weak ground.

The conclusions of R. Hannah's article deserve attention: they are moderate and, without suggesting that on a particular important hour the shadow of the obelisk pointed towards the Ara (probably meaning the centre of the Ara and therefore its axis of symmetry), he insists that the shadow pointed towards the Ara during Augustus' birthday. ${ }^{46}$ Nevertheless, his support for the existence of a Horologium Solarium and not of a simple solar meridian (as it is proven both by the archaeological evidence so

${ }^{40}$ HANNAH (n. 26) 89.

${ }^{41}$ HANNAH (n. 26) 90-91.

${ }^{42}$ HANNAH (n. 26) 92-93 (ill.) and 93-95.

${ }^{43}$ HANNAH (n. 26) 91 and 94.

${ }^{44}$ Mainly that M. Schütz had not taken into account the whole length of the gnomon-obelisk's shadow; even R. Hannah admits that the elliptical shadow of the bronze globe obelisk represents the tip of the whole shadow left by the entire obelisk; see HANNAH (n. 26) 91, n. 13-16 for his own precise calculations.

${ }_{46}^{45}$ HASELBERGER (n. 26) 61-62 (61, fig. 10; 63, fig. 11). 
far available to us as well as by the more plausible theory of M. Schütz) is disputable, to say the least. According to R. Hannah's calculations the shadow of the gnomonobelisk would have not touched the Ara between roughly the 7th of November and the 5th of February, leaving therefore out of question the moment of Augustus' conception under the sign of the Capricorn, around the winter solstice. Varro (RR 1. 28. 1-2) wrote that, according to the old Roman calendar of King Numa Pompilius, the first day of spring occurred on the 23rd day of Aquarius, the first day of summer on the 23rd day of Taurus, the first day of autumn on the 23rd day of Leo, and the first day of winter on the 23rd day of Scorpio. In the new Julian calendar these dates would have been approximately our days named 7th of February, 9th of May, 11 th of August (Sextilis mens according to the oldest Roman calendar of Romulus, where the year beginning is on the 1st of March), and the winter would have begun around the 10th day of November. ${ }^{47}$ In conclusion, R. Hannah suggests that the virtual or imaginary line left by the gnomon-obelisk's shadow towards the Ara could have marked a temporary boundary between the seasons of the year, by its very presence or absence (in the interval between the 7 th of November and the 5 th of February). ${ }^{48}$

The conclusive remark on this issue is that of the great scholar Géza Alföldy: although he is more inclined to the traditional thesis of E. Buchner about the Horologium Solarium. Like L. Haselberg he acknowledges that the actual form and dimensions ("spatial expanse") of this kind of putative Augustan sundial remains unknown. Moreover, he tries to see it in connection with a possible model of a gnomon-obelisk and Horologium Solarium in Alexandria in Egypt, probably constructed by the initiative of Marc Anthony, Octavian's sworn enemy in the final struggle for the domination of the Roman Empire. He correlates the obelisk of Montecitorio, dedicated originally by the ancient Egyptians to the sun god (Sol for the ancient Romans) and brought there by the order of Augustus with the obelisk currently in the present-day St. Peter's Square in Vatican City. It was brought, erected, and consecrated there by Caligula in his Circus Vaticani (both obelisks share similarities in shape, including the bronze globe with a spine on top, a Hellenistic-Roman innovation by no means similar to the ancient Egyptian tradition). G. Alföldy quotes, as examples of this Egyptian fashion of the obelisks, the two smaller obelisks that were originally placed in the front of the Mausoleum Augusti; the triangular composition of the three Augustan obelisks, two smaller in the front of his Mausoleum and one in the vicinity of the Ara would have found parallels in Alexandria of Egypt, ruled first by Cleopatra VII and Marc Anthony, and then by Augustus' trusted men, Caius Cornelius Gallus his praefectus fabrum and the first praefectus Aegypti and then by the second prefect of Egypt, Publius Rubrius Barbarus. This last character had actually erected two obelisks at Alexandria in the front of Augustus' temple there, while Augustus was still alive, in the years 1312 BC. Moreover, the Vatican obelisk brought by Caligula from Egypt to Rome was already inscribed and inaugurated by C. Cornelius Gallus in late $31 \mathrm{BC}$, while he was still only Octavian's praefectus fabrum; this obelisk could have been originally

${ }^{47}$ HANNAH (n. 26) 94, n. 19; see also Plin. $N H$ 18. 221-222.
${ }^{48}$ HANNAH (n. 26) 94-95.

Acta Ant. Hung. 55, 2015 
a monument ordered by Marc Anthony as gnomon of a gigantic sundial at Alexandria of Egypt, in the same area of the city with the obelisks later associated with P. Rubrius Barbarus. Interestingly enough, it is the same period of time (13-9 BC, 13-12 BC, and respectively 10-9 BC) correlated with the construction of both the Ara Pacis and the erection of the gnomon-obelisk in the northern Campus Martius. The inscription in Greek ETE $\Sigma$ IAI ПAYONTAI that we find on the Flavian meridian was probably a truthful reproduction of the Augustan original inspired by a Greek-Egyptian model from Alexandria. ${ }^{49} \mathrm{G}$. Alföldy concludes on a similar tune with L. Haselberger: there existed a Horologium Solarium Augusti in the northern Campus Martius and it was important for establishing the calendar as well as showing to the ordinary Romans who was really in charge in Rome and beyond, not only in solving problems pertaining to the sphere of mortal humans, but also with regulating time that was the province of the gods. ${ }^{50}$

The problem of the true identity of the Ara now housed by the Museo del Ara Pacis in Lungotevere was seriously taken into account starting from 1960; while in the Renaissance (the 16th century) the fragments discovered from the Ara were considered parts of Roman triumphal monuments, only in 1879 the archaeological genius of Friedrich von Duhn had the intuition that all the fragments discovered under the Ottoboni-Peretti-Fiano Palazzo in the region of Via and Piazza San Lorenzo in Lucina in the Campo Marzio (Rome) were in fact parts of the famous Ara Pacis Augustae, mentioned in the Res Gestae Divi Augusti 12. 2. ${ }^{51}$ However, in the year

${ }^{49}$ Alföldy (n. 26) 96-97; HASElBerger (26) 68-69. C. H. LANGE (Res Publica Constituta. Actium, Apollo and the Accomplishment of the Triumviral Assignment. [Impact of Empire. Vol. X]. LeidenBoston 2009, 6-7) is nevertheless more inclined to accept M. Schütz's theory: "Sadly, this theory (i.e., E. Buchner's) did not stand the test of time and a physicist from Tübingen" (i.e., M. Schütz).

${ }^{50}$ ALFÖLDY (n. 26) 98 for the importance of the existence of a Horologium Solarium in the self representation of Augustus before the Senate and the People of Rome; HASELBERGER (n. 26) 69-70 about the symbolic importance of the ensemble Horologium Solarium Augusti-Ara Pacis Augustae in the Augustan urban transformation of Rome and in regulating chronology and civic life in Rome and in the Roman Empire according to the cosmic cycles of heavens.

${ }^{51}$ LA RoCCA (n. 1) 11-13 for the Res Gestae 11-13 and the monuments directly connected by symbolical and ideological links with the Ara Pacis, namely the Ara Fortunae Reducis and the Aedes Iani Quirini in Argileto. An interesting fact is that, according to Cass. Dio (Hist. Rom. 54. 25. 3), the Roman Senate had initially decided to erect the Ara Pacis inside the Curia Senatus; Augustus had in fact refuted this idea and preferred the Northern Campus Martius, see RossiNI (n. 6) 5. The first recuperated fragments of the Ara Pacis appear in fact from an incised drawing or engraving made by Agostino Veneziano before 1536; it was about the lower outer frieze, with a swan with spread wings and the floral and vegetal decoration. In 1566 the cardinal Giovanni Ricci da Montepulciano acquired nine marble blocks for a price of 125 scudi, including the so called Tellus-Pax panel. The cardinal's secretary had in fact even written a letter to the secretary of the Grand Duke of Tuscany Cosimo I of Medici in 1569, telling him by means of this letter that these sculptural friezes are Roman reliefs with triumphal figures ("con figure di trionfi"). After a troubled history that brought recovered fragments of the Ara to Florence, to the future Villa Medici at Trinità dei Monti, to the Villa Aldobrandini on the Quirinale in Rome, and even to Paris (Louvre), only in the year $1879 \mathrm{Fr}$. von Duhn recognized the ensemble of the recovered fragments from that area as component elements of the Ara Pacis. There followed in the period of 1894-1903 the archaeological diggings under the Palace Ottoboni-Peretti-Fiano-Almagià, directed by Eugen Petersen and Angelo Pasqui, stopped by technical reasons. In 1913 A. Pasqui had tried again in a letter to convince the Italian government to financially and legally support the excavations. Only in 1937-1938 the archaeological team led by 
1960 S. Weinstock in an article published in the famous Journal of Roman Studies questioned and even denied this identification, mainly on the ground of iconographical evidence. His objections were met and countered with equally serious iconographical, architectonical, and logical arguments by another important researcher in this field, J. M. C. Toynbee, in another article published in the same Journal of Roman Studies the following year. ${ }^{52}$ Without entering in the details of their discussions and arguments (revolving mainly on the identity of the deity worshipped in the Ara), one should mention here that for Stefan Weinstock this Ara could not be securely identified (but for him it was surely not the Ara Pacis Augustae, perhaps being the Ara Gentis Iuliae that nevertheless, at least under Vespasian, was located on the Capitol and not in the Campus Martius, where there were other monuments: Monumentum Iuliorum, Ustrinum Domus Augustae, Mausoleum Augusti). ${ }^{53}$ The counter arguments brought in by J. M. C. Toynbee against the thesis of S. Weinstock were summed up in his memorable conclusion: "Dr. Weinstock has most forcibly reminded us that we have no ineluctable, explicit proof that the Campus Martius Augustan altar is the Ara Pacis Augustae. But he has not, to my mind, succeeded in proving that it is certainly not the Ara Pacis Augustae." 54

The most important fact is that we do not possess until now any dedicatory inscription of this most important monument of Roman Augustan Art and therefore we cannot attribute it for sure to the goddess Pax or Tellus, etc. One cannot epigraphically relate directly the altar to the Res Gestae Divi Augusti 12. 2 in absence of a monument's own inscription that defines its function and meaning. However, its location, much of its iconography and symbols hint at the cult of Pax and of the goddesses related with agricultural plenty and richness, with wealth, happiness, and fruitful love (fertility of the plants, sexual reproduction of cattle, and by implication, fecundity of women and men; the reform of the marital and sexual mores of the Roman citizens, the stability of marriage, family, and the conception, birth, and upbringing of legitimate free Roman children was one of the concerns involving the inner policy of Augustus, a fact that is known by all scholars specialized in the field of Ancient Roman History). It is also related with Roman religion (rituals, ceremonial processions or gatherings for sacrifices), with the mythology of the Primordia Romae and with the Origines of the people from Latium. One cannot help of not thinking at the Ara Pacis Augustae mentioned by the Res Gestae Divi Augusti 12.

Accepting the theory that the monument exposed now in the Museo Del'Ara Pacis is the true Ara Pacis Augustae, we can form the final conclusions of the true meaning rendered by the friezes of the monument. We can see the meaning (especially that of the outer upper friezes) as an embodiment in stone of the Augustan idea of the Parta Victoriis Pax, the Roman Augustan Peace (Pax Romana Augusta) born out of military victories, the victory being a real one or an imagined one (like Augustus'

Giuseppe Moretti and (for the restoration) by Guglielmo Gatti, using innovative techniques, had achieved the excavations and restoration of the whole monument, see ROSSINI (n. 6) 14-17.

${ }^{52}$ Weinstock (n. 4) 44-58; contra ToynBeE: The Ara Pacis (n. 36) 153-156.

${ }^{53}$ WEINSTOCK (n. 4) 58.

${ }^{54}$ TOYNBEE: The Ara Pacis (n. 36) 156; contra Weinstock (n. 4$) 58$. 
diplomatic triumph in the negotiations with the Parthians, in the year $20 \mathrm{BC}$, over the legionary eagles and standards lost by the Roman legionaries commanded by Crassus in the battle of Carrhae in $53 \mathrm{BC}$ and captured by the Parthians). In essence, one can see the Ara Pacis Augustae as the embodiment in carved Luna/Carrara marble of an idea: it is an epic poem that renders in sculptural form the mythology of the origins of Rome, Latium, and Italy and that binds inextricably the divine origin of the Gens Iulia (and therefore of both Caesar the Divus Iulius and Augustus the Divus to be), descending from the goddess Venus (via Aeneas and his son Iullus Ascanius), with the origins of the Roman people, descending from Mars; the Romans, being under the protection of Jupiter the King of the gods, like once Romulus the son of Mars and founder of Rome, they are destined to rule over the peoples of the earth and to impose peace (Verg. Aen. 6. 851-853: Tu regere imperio populos, Romane memento: Hae tibi erunt artes, pacisque imponere mores, parcere subiectis et debellare superbos). The panels with the nourishing goddess and with the triumphant Dea Roma (the eastern upper friezes of the external precinct of the Ara) hint at another idea, dear to both Augustus and Virgil: Sit Romana potens Itala virtute propago" (Verg. Aen. 12. 827). ${ }^{55}$

To sum up, one should not forget the original orientation of the facades of the Ara Pacis Augustae: if the hypothesis of M. Schütz ${ }^{56}$ is correct and the viewer that stood in the front of the eastern façade of the Ara Pacis Augustae at the Parilia (21st of April, the Birthday of Rome) could have seen, in Augustus' lifetime, the rays of the sun entering the eastern entrance of the altar, then the message transmitted by Augustus and by the anonymous sculpture master entrusted with the iconographical and architectural design of the whole monument to posterity is subtler than E. Buchner, in all his undeniable wisdom and experience, had ever imagined: instead of the shadow of the obelisk entering the western entrance on Augustus' birthday (23rd of September), as if the Heaven itself testified that Augustus was natus ad pacem, we stumble upon the assertion of Rome as bringer of peace and prosperity: the armed Dea Roma and the weaponless but beautiful Pax are the two faces of the same coin. ${ }^{57}$

${ }^{55}$ POllini, J.: ,Frieden-durch-Sieg'-Ideologie und die Ara Pacis Augustae. In BIETAK, M. SCHWARZ, M. (eds.): Krieg und Sieg Narrative Wanderdarstellungen von Altägypten bis ins Mittelalter. Wien 2002, 137-157. See also Polacco, L.: Ara Pacis Augustae. Una forma, un' idea [Atti Classe di Scienze Morali, Lettere ed Arti. Vol. CI. 1991-1992]. Venezia 1992, 9-31.

${ }_{57}^{56}$ SCHÜTZ: The Horologium (n. 4) 86.

${ }^{57}$ Because of the archaeological evidence discussed so far, as well as because of the mathematical experience and professionalism of M. Schütz, I am personally inclined to adopt his theory of the solar meridian, although I do not agree with S. Weinstock's denial of the identity of this altar as being the true Ara Pacis Augustae. Moreover, I personally think that M. Schütz's theory could confirm or infirm what I have personally written in a previous study about Alexander the Great and Augustus. I hereby reproduce my own hypothesis. I see the symbolic of the Ara Pacis reliefs as follows:

The west is the realm of origins, of mythos, the land of the heroes of old and the space of the gods founders of Rome: Jupiter, Mars, and (indirectly) Venus (through her son Aeneas). Aeneas and the legendary twins Romulus and Remus are also hewn in stone here. It is a cardinal point used with the same symbolic in other mythic traditions: in Greek myth Heracles went west to find the golden apples of the Hesperidae, symbols of eternal youth and immortality. In the Roman foundation myth, Aeneas and his son Iulus Ascanius and the surviving Trojans (preceded by the Arcadians of king Evander that had settled on the Tiber, in the future territory of Rome), after the fall of Ilium went also west via Africa, Sicily, arriving eventually on the western coast of central Italy, in order to merge with the Aborigines of king Latinus. 


\section{CONCLUDING REMARKS}

It is an inherent probability that the new theory (or rather hypothesis) regarding this Ara to be the right one ${ }^{58}$ In favor of this idea that sees the original eastern façade and entrance to the monument as the one marked by the rays of the sun on the 21st of April (the Roman Feast of the Parilia) are the mathematical and astronomical expertise of the German physicist Michael Schütz; even he, however, makes that claim as an hypothesis and not as a proven fact (because of the unclear data about the true number of pedestal steps of the basis of the gnomon-obelisk, according to the Stuart-BandiniDe Marchis report of 1748-1750; the true and precise location and the exact height of the original Augustan obelisk determine the trigonometric computations and results). What remains for certain is that during the autumnal equinox (21st-23rd of September), and therefore during Augustus' birthday feast (the 23rd of September/Dies Natalis) the shadow of the gnomon-obelisk did not fall on the precise axis of symmetry of the western entrance to the Ara, but it fell rather slantwise, in a direction oblique to the axis of symmetry (this axis of symmetry is the perpendicular line to the entrance and therefore to the geometrical middle/centre of the western façade). Even so, although the shadow did not fall perpendicularly into the Ara through the western gate, it nevertheless fell obliquely towards the western façade of the Ara. In the eventuality that M. Schütz's hypothesis is correct; the design created by the anonymous master or masters that brought the Ara into existence reflects in a wonderful way the Augustan ideas about the majesty of Rome: the sun lit the eastern entrance of the Ara on Rome's Founding Day, during the Feast of the Parilia. The Eternal City founded by the warlike son of Mars, Romulus, was now, during Augustus' benevolent

\footnotetext{
After mythical and epic heroic events narrated by Vergil and Livy, Aeneas married princess Lavinia, the daughter of king Latinus of Lanuvium. Thus was founded the Latin people and so appeared the birth of the Latium land and of the cities of Lavinium and Alba Longa, Latin settlements or towns predecessors of Rome. In the Greek Romance of Alexander (Pseudo-Kallisthenes), Alexander the Great, like a new Ghilgamesh seeking the Immortality grass/herbs, search for the Immortality fount in the west. In Irish (Celtic Gaelic) mythical epics, stories, and poems, the heroes travel west in search of the blessed islands of the Immortals, in the mythical Tir na'nOg (the land of the eternal youth). Finally, in the old Egyptian tales, the sun god Amun-Ra travels the lands of the west every night with his boat, in order to be reborn the next day in the east. See MARKALE, J.: L'Épopée celtique d'Irlande. Paris 1971, and BACHMANN, P.: Der mit den zwei Hörnern. Alexander der Große in Werken der arabischen Literatur. Mainz am Rhein 2005.

The east is the realm of Eternal Peace seen as Eternal Present, the realm of the gods protectors of Augustus: the swans and the acanthus flower decorations carved in stone are all symbols of Apollo, Augustus' personal protector god. Dea Roma and Tellus/Venus/Pax are also present.

The north is home to the children of the Imperial family, to the offspring of Rome, and there are also sculpted a part of the state officials and priesthood of Rome (the augures, who told the future divining the flight of the birds and the septemviri epulonum, the organizers of the public feasts are represented here). It is the space of the future of the Eternal City.

The south, oriented forever towards the Urbs, it is the processional space of Augustus himself, of Agrippa his best and truest friend and collaborator, and of the most sacred priests of Rome, the collegia flaminum. It is the space of the civic and sacral (or political and religious) eternal present of Rome. This is of course a personal interpretation and it should be taken as such. See IONESCU: Alexander's Monarchy (n. 26) 62-64 and IONESCU: The Ara Pacis (n. 26) 150-152, n. 113-115.

${ }^{58}$ SCHÜTZ: The Horologium (n. 4) 86.
} 
Principate, under the sway of the Pax Augusta (see the symbolism of the eastern façade of this monument). During Augustus' birthday, the shadow of the gnomon-obelisk falls obliquely towards the Ara, pointing in an indirect way to the Primordia Romae and to the Origo Gentis Iuliae, the Roman clan that eventually had produced Julius Caesar, the adoptive father of Augustus. The light comes from the East from Aeneas' Trojans, and before them from Heracles/Hercules and King Evander's Greeks, who once came and settled in Latium (first in Lanuvium and then founding, in the process, the new towns of Lavinium and Alba Longa) and on the Seven Hills of Rome. From there, the West is, on the 23rd of September, under the shadow of the gnomonobelisk, conserving the memory of Aeneas (or that of Numa Pompilius) and of the heroic Twins-founders of Rome, the sons of Mars and Rhea Silvia, Romulus and Remus. In the person of Augustus, the original fratricide that stood at the very foundation of Rome is thus at least symbolically mitigated. It becomes not a simple brother killing brother in the struggle for power, but a non-represented human sacrifice, as necessary to the founding of the Urbs and to the future of the ancient known world as it was for the coming of Aeneas and his Trojans to Italy's seashore, or to the divine lovemaking between the Italic war-god Mars and the Vestal Virgin Rhea Silvia. In the seduced Vestal's veins flowed the blood of Aeneas, son of Anchises, and of Venus-Aphrodite, Aeneas' mother and the goddess of love and beauty. Thus, indirectly, in the Roman myth, as in the original Greek one, the act of lovemaking between the war god Ares and the love goddess Aphrodite produced the daughter Harmonia, the prerequisite to the reign of Peace. ${ }^{59}$

Dr Dan-Tudor Ionescu

Research Assistant

Metropolitan Library Bucharest

Romania

dantudorionescu@gmail.com

${ }^{59}$ IONESCU: The Ara Pacis (n. 26) 151-152. 